University of Warwick institutional repository: http://go.warwick.ac.uk/wrap This paper is made available online in accordance with publisher policies. Please scroll down to view the document itself. Please refer to the repository record for this item and our policy information available from the repository home page for further information.

To see the final version of this paper please visit the publisher's website. Access to the published version may require a subscription.

Author(s): CHRISTOPHER W. HUGHES

Article Title: The Political Economy of Japanese Sanctions Towards

North Korea: Domestic Coalitions and International Systemic Pressures Year of publication: 2006

Link to published version: http://pacificaffairs.ubc.ca/recent/ab79-

3.html\#hughes

Publisher statement: none 


\title{
The Political Economy of Japanese Sanctions Towards North Korea: \\ Domestic Coalitions and International Systemic Pressures
}

\author{
Christopher W. Hughes, University of Warwick
}

\section{Introduction}

Japan has often been dismissed as a bit part actor in Korean Peninsula security affairs. Japan, in much of the mainstream academic literature and policy discourse on the North Korean security issue, if ascribed any role at all, is seen as a secondary and submissive diplomatic actor: functioning chiefly to support US and South Korean initiatives towards the North through the provision of potential economic incentives; and generally bending to US strategy, whether in the bilateral context of the US-Japan alliance, or the multilateral contexts of the Trilateral Coordination and Oversight Group (TCOG) and ongoing Six Party Talks (SPT). ${ }^{1}$ Japan's role in the North Korean security issue would thus appear in line with many other traditional interpretations of its international relations as submissive to US strategy and international systemic pressures.

More recently, though, academic commentators and policy practitioners have shown a new awareness that Japan's own bilateral agenda and domestic political conditions are rising in importance relative to international factors in determining its overall policy orientation towards the North. Bilateral tensions over the abductions of Japanese citizens (rachi jiken), and subsequent moves in Japan to enact legal conditions for the unilateral imposition of sanctions on the North-and thereby to shift its declared 
policy of a balance of "dialogue and pressure" (taiwa to atsuryoku) towards pressure and containment - have particularly highlighted the influence of domestic political considerations. In turn, Japan's preoccupation with domestic political pressures has clearly impacted upon its flexibility and compliance as a partner in international strategies to deal with the North. The Japanese Ministry of Foreign Affairs' (MOFA) persistent raising of the abductions issue at all rounds of the SPT has produced some disquiet amongst their US, South Korean and Chinese counterparts that North Korea may use this as an additional pretext to evade negotiations, and, hence, that an essentially Japanese domestic and bilateral issue may trump the progress of multilateral efforts on the North's nuclear programme. ${ }^{2}$

Indeed, the argument of this article is that the abductions issue, and the intimation that it provides of the importance of domestic politics, is really only the tip of the iceberg of deeper lying domestic and bilateral concerns that are hampering progress in JapanNorth Korea relations. It is crucial not be blinded to the domestic sources of Japan's foreign policy in order to understand the nature of its relationship with the North, and concomitantly with the US and South Korea. This article argues that, whilst international systemic pressures have often been and still remain decisive in many instances for influencing the direction of Japan's North Korea policy, it is equally important to recognise that an over-concentration on international factors can obscure crucial domestic explanations that account for Japan's approach to the North, and can so lead to mistaken academic and policy analysis. Hence, this article seeks to add to those existing approaches that lift the lid on the proverbial 'black box' of the Japanese policymaking system and to demonstrate the increasingly important role of domestic political and bilateral concerns, alongside international concerns, in driving its North 
Korea policy. In fact, this article argues not only for the need to factor in domestic politics as of mounting importance in shaping Japan's North Korea policy, but also for the need to recognise that in certain instances domestic pressures are threatening to outstrip international pressures as the prime determinant.

These arguments also have important implications for understanding Japan's general diplomatic standing in Korean Peninsula security affairs. For if the Japanese foreign policymaking process, as a result of domestic political pressures, demonstrates signs of shifting to a policy of containment of the North through the imposition of unilateral sanctions, or experiences increasing obstacles to providing active support for US strategy, then this could derail US-Japan bilateral and US-Japan-South Korea trilateral cooperation efforts, as well as hinder greatly the process of the SPT, and any other internationally co-ordinated attempts in the future to resolve the nuclear issue. In this way, Japan's domestic political pressures, and how they impact on the level of Japanese cooperation with the US, South Korea and other states, magnify the influence of Japan as an actor in Korean Peninsula security affairs; even if that influence may ultimately obstruct progress on a resolution to the nuclear issue.

\section{Theories and methodology}

This article does not reject standard 'realist' varieties of international systemic or structure-based explanations for Japan's foreign policy and international relations that tend to see it as highly sensitive and often submissive to external power relationships with other states and particularly its US ally. ${ }^{3}$ Instead, it proposes that these international systemic explanations need to be employed in conjunction with, and weighed against, pressures emanating from the domestic policymaking process. This 
is in line with other more recent theoretical and empirical case studies that emphasise the importance historically of pluralistic domestic policy interests, such as party politics, domestic administrative institutions, and public opinion, in countering or even overcoming international systemic pressures on Japan's security and foreign policy orientation. ${ }^{4}$ However, this article also aims to build upon and provide a distinct contribution to this literature by going beyond highlighting the importance of domestic variables per se, and now indicating a set of dynamic processes and circumstances which account for why and when domestic political pressures can accumulate to the point that they may rival international systemic pressures in determining foreign policy.

The specific case study that this article utilises to examine the varying strengths of international pressures and pluralistic domestic agency in determining Japan's North Korea policy is that of the deliberations concerning the imposition of sanctions. The case of sanctions is intrinsically important in itself, given that Japan's decision about their imposition may hold the key to determining the degree of its cooperation with US and other concerned states' strategies towards resolving the nuclear issue. This article makes no attempt to examine the actual effectiveness of sanctions on North Korea. This is beyond the scope of this article, and the focus is solely on explaining the political process behind any decision to impose sanctions. ${ }^{5}$

Sanctions theory is especially useful because it indicates that, whilst in many cases 'realist' explanations of international systemic coercion and offers of side payments may account for states' decisions to cooperate or not over the imposition of sanctions, in other cases domestic political and economic interests may prove just as dominant in 
sanctions behaviour. ${ }^{6}$ This strain of sanctions theory, much drawn from the public choice literature, but also much qualitative in nature, provides a number of domestic political economy-focussed explanations for the imposition of sanctions. It indicates a pluralistic range of domestic policy actors_-including bureaucratic and political elites, business interests, public opinion and special interest groups - that are crucial in lobbying for or against state action in the imposition of sanctions. ${ }^{7}$ It further indicates that these domestic actors will be in a position to tip central government policy towards sanctions when they are able to form a sufficiently strong coalition amongst themselves. These 'log-rolling' or 'threshold' coalitions result from the actions of leading key members of the coalition that are able to motivate others for collective action. $^{8}$

Motivations for the imposition of sanctions are multifarious and not necessarily mutually exclusive. They include 'instrumental sanctions' that are attempts by the sender state to effect genuine policy change in the target; 'expressive sanctions' that represent a desire for moral and psychological assurance and to 'do something', short of more costly military measures, in protest at the actions of the target state; and sanctions that may function more for the pecuniary and political interests of domestic actors because they provide protection for domestic industries or political credit for being seen to take action against an abhorrent target state. ${ }^{9}$ Moreover, the fact that the formation of domestic coalitions in favour of sanctions is often dependent on the ability to motivate particular interest groups means that smaller coalition actors are particularly effective in exploiting the opportunities to leverage the collective interests of the coalition against the central government. Hence, this means that in practice coalition groups that reflect a narrow range of motivations, even if they portray or 
perceive themselves as in the interest of the majority, can override the influence of larger and more powerful domestic actors. ${ }^{10}$ Also this means that if genuinely powerful domestic groups choose not to participate in the domestic contestation over sanctions, then, by default, less powerful interest groups may actually dominate the policy outcome due to their coalition-building abilities. Finally, this ability of coalitions of domestic political actors, often orchestrated by minority interests, to capture state policy can also lead to instances whereby states pursue the imposition of sanctions in contravention, or irrespective, of international pressures.

It is the contention of this article that Japan's policy towards North Korea has shown increasing signs in recent years of being driven by domestic over international pressures; and based on sanctions theory it is this article's further contention that this move towards sanctions is the result of the formation of a 'threshold' domestic coalition that seeks to contain rather than engage the North. Arguably, this marks a potentially decisive turn in Japan's policy orientation. This is because in previous years either the international pressures were great enough to prevail over relatively weak domestic coalitions, or because relatively strong domestic coalitions were actually in favour or engaging North Korea, thus making for policy outcomes in line with international pressures and usually predisposed to engagement rather than containment.

In order to substantiate these arguments this article is divided into two empirical sections. The first section provides an overview and analysis of Japan's relations with North Korea from the early 1990s to the present day, punctuated by special examination of three instances in 1993-1994, 1998-1999, and 2003-2006, of Japan's 
consideration or actual imposition of a range of sanctions on North Korea. This overview demonstrates the fluctuating importance over time of international pressures in influencing Japan's policies of engagement and containment towards the North, but also how Japanese domestic political and bilateral concerns have intervened, with varying degrees of influence, to further shape policy outcomes. The second section then moves to explain this varying influence of domestic political and bilateral concerns vis-à-vis international pressures on Japan's sanctions policy. It does so by analysing in detail the nature of the extant domestic political coalitions, and the policy interests of their various constituent political and economic actors. It demonstrates that by aggregating these interests, then the relative strength and cohesion of domestic political coalitions overtime can be judged, and hence so can their relative strength vis-à-vis international systemic pressures. It argues that, based on current evidence, a strong domestic coalition has indeed coalesced in Japan in favour of sanctions, more prepared than at any time over the previous decade and a half to challenge, and even overturn, international systemic pressures. In turn, this detection of an emergent threshold coalition provides important insights into understanding the dynamic process of how and when domestic variables rise to reinforce or challenge international systemic factors in Japan's North Korea policy and its foreign policy more widely.

\section{Japan's engagement and containment of North Korea: international and domestic pressures}

In terms of international systemic pressures, Japan's government has sought to emphasise that it retains control over bilateral relations with North Korea, but it has also stressed that its policy largely conforms with the mix of containment and 
engagement policies of the US and South Korea. In terms of domestic politics and bilateral issues, as will be seen in the next section, a number of actors-including MOFA, elements of the governing Liberal Democratic Party (LDP) and the opposition parties, as well as business interests, the North Korean community in Japan, and single-issue pressure groups - have been involved in making diplomatic relations with North Korea.

Japan's optimum long-term strategy, and the one accepted by the most influential policymakers for dealing with North Korea has been one of engagement. However, as will be seen from the following overview of Japan-North Korea relations over the last decade, Japan has not always found it possible to maintain a constant policy line towards the North

Phase 1: Normalisation talks and the first nuclear crisis, 1990-1995

Japan's first opportunity for full engagement with North Korea arrived with the end of the Cold War, which lessened the international pressures on Japan to cooperate in the containment of the North. This produced the opportunity for Kanemaru Shin's visit to North Korea and issuance of the Three-Party Joint Declaration in September 1990, and then the opening for government-to-government normalisation negotiations from January 1991 to November 1992. The progress (or lack of it) of these negotiations has been detailed elsewhere. However, it is important to note here that their failure was principally the result of Japanese domestic political and bilateral issues with the North, including the colonial and postwar apology and compensation issues, the Nihonjinzuma, and the first raising of the abductions issue. 
In addition to these bilateral and domestic issues, though, a further decisive brake was placed on Japan's normalisation and engagement efforts by the rise of new international systemic pressures. Firstly, Japan was obliged to reassure an anxious South Korean government that it would only pursue negotiations in parallel with progress in North-South dialogue. This policy of linkage (renkei) was not formally binding, but in reality was the start of MOFA tying Japan's diplomacy more closely with that of South Korea, and of the formation of one side of the emergent trilateral framework of US-Japan-South Korea diplomatic cooperation. The practical outcome of Japan's renkei policy was to impose a near international 'double-lock' on its diplomacy with the North: obliging it to consider the restart of normalisation talks with North Korea in step with improvements in North-South relations, which in themselves were largely contingent on improvements in US-North Korea relations.

Secondly, Japan's inability to engage North Korea was compounded in this period by the international pressures of US-North Korea confrontation during the first nuclear crisis of 1993-1994. Japan was at this point forced to consider a switch to containment through the participation in US-led sanctions against the North, including the cessation of remittances by the North Korean community in Japan, and the participation of the Japan Self Defence Forces (JSDF) in a naval blockade. Japanese policy was eventually averted from sanctions by the combined intervention of domestic politics and the receding of international pressures. LDP and then coalition Japanese governments between 1993 and 1994 indicated to the US that Japan would be hard-pressed politically and militarily to support the imposition of sanctions. Japan was then saved from a confrontation with the US over its credibility as an alliance partner by the US's own shift towards engagement with North Korea and the Agreed 
Framework of October 1994. Hence, in this first phase of Japan-North Korea relations, concluding with the consideration but then rejection of sanctions, it can be seen that Japan avoided moves towards containment because of domestic political conditions predisposed more towards tentative engagement, and because of an international system that first threatened to challenge but then reinforced this position.

\section{Phase 2: KEDO and the 'Taepdong-shock', 1995-2000}

Japan's second phase of dealing with North Korea was marked by the rise of an international environment generally conducive to engagement with North Korea. The US moved towards careful engagement with North Korea through the Agreed Framework, the establishment of the Korean Peninsula Energy Development Organisation (KEDO) in March 1995, and then, following the October 1998 Perry Report, through the visit of Secretary of State Madeleine Albright to Pyongyang in November 2000. Similarly, South Korea moved to engage North Korea through President Kim Dae-Jung’s ‘Sunshine Policy’.

Despite the relatively propitious international situation that lifted the double-lock on its diplomacy, however, in this period Japan encountered increasing domestic and bilateral obstacles to engaging North Korea. Japan attempted to restart normalisation talks through former Foreign Minister Watanabe Michio's LDP-SDPJ-Sakigake delegation to the North in March 1995, the government's provision bilaterally of 500,000 tons of rice aid in June and October, and Mori Yoshirō's LDP-SDPJSakigake mission to the North in November 1997. But increasing domestic pressure over the Nihonjinzuma and abductions issue effectively blocked the restart of normalisation negotiations between 1995 and 1997-1998. North Korea's test launch 
of a Taepdong-1 ballistic missile over Japan on 31 August 1998 then pushed Japan towards the containment of the North through the imposition of limited sanctions. Japan's government announced the suspension of its signing of the KEDO funding agreements, to which it was expected to contribute approximately US\$1 billion; the stoppage of food aid and normalisation talks, and thus the North's access to a believed figure of up to US\$10 billion in Official Development Assistance (ODA) as part of Japan's package for settling the colonial past; and the cancellation of charter flights between Japan and North Korea, many of which were used to carry North Korean agricultural commodities to Japan such as high-priced matsutake mushrooms. ${ }^{11}$ Japanese politicians also mooted proposals to cut remittances to North Korea as in the 1994 nuclear crisis.

Japan's domestic political pressures in this period were insufficient, though, to overcome the strength of international pressures. Japan was persuaded by US and South Korean policymakers to sign the KEDO agreements in October 1999, to lift its other sanctions by December 1999, and to restart bilateral normalisation negotiations between April 2000 and October 2001. Japan prepared the grounds for these talks by the dispatch of former Prime Minister Murayama Tomiichi's mission to the North in November 1999 , and by the provision of 100,000 and 500,000 tons of rice aid via the World Food Programme (WFP) in March and October 2000. Japan thus moved back into step with the US and South Korea, although its reaction in the post-'Taepodongshock' period was a portent of the increasing strength of domestic forces oriented towards containment in shaping its North Korea policy.

Phase 3: Koizumi's summitry and sanctions, 2001-2006 
In this third phase Japan has been confronted by the closing in once again of international pressures, resulting from the US's enhanced hard-line approach towards North Korea over its nuclear programme, especially in the early stages of the first Bush administration, and the North's response of ratcheting up military tensions. In the situation of the collapse of the Agreed Framework, and the restart of the North nuclear programme, Japan has been faced with increased pressure to adhere to the US policy line, mindful as it is of its need to rely in large part on the US for its security. At the same time, the domestic pressures on Japan's policy towards North Korea to lean towards containment have also grown, with MOFA stressing by 2002 that the settlement of the abductions had now become the official precondition for the restart of normalisation negotiations.

The Japanese government's sandwiching between these international and domestic pressures has created for Japan an uncomfortable strategic situation. On the one hand, whilst highly concerned about the North Korea's nuclear programme and the need to maintain confidence in the US-Japan alliance to deter the North, Japan has been concerned that the US hard-line approach might lead to renewed military confrontation. On the other, Japanese policymakers have been aware that the growing domestic pressure in favour of the containment of the North has undercut its diplomatic flexibility to support the US in the event of its shifting back towards engagement.

Japan subsequently sought to break this deadlock with Prime Minister's Koizumi's summitry with North Korea in 2002 and 2004. ${ }^{12}$ Koizumi's September 2002 summit with Kim Jong-Il produced the 'Japan-DPRK Pyongyang Declaration', significant 
progress on the abductions issue, and the resumption of normalisation talks in October 2002. However, the talks subsequently stalled over Japan's insistence that the surviving abductees should be permitted to remain permanently in Japan and the Jenkins case. Koizumi then pushed bilateral ties further forward with his second visit to Pyongyang in May 2004, and a pledge of 250,000 tons of food aid to the North, leading to continuing discussions into the fate of the non-surviving abductees, and an eventual resolution of the Jenkins case in late 2004. Japan-North Korea bilateral talks then foundered in December 2004 over the Yokota Megumi controversy.

Japan's bold diplomacy under Koizumi was motivated by several calculations, Firstly, although informed by concern over the North's nuclear programme and the need to line up with the US in the final instance to take action against the North, Japan's policymakers were also convinced of the need to demonstrate to the US the need to attempt engagement in order to avoid conflict with the North. Secondly, Japanese policymakers were conscious that the abductions issue had to be addressed head on as the key domestic factor militating against Japanese diplomatic flexibility. ${ }^{13}$ Japanese diplomacy can in many ways be seen to have achieved greater autonomy with Koizumi's visits to North Korea. Koizumi directly and successfully challenged the tightening international pressures by visiting North Korea in spite of US disquiet, and thus carved out more diplomatic freedom for Japan. Koizumi's diplomacy also challenged bilateral and domestic constraints by ensuring that North Korea acceded to Japan's negotiating demands for normalisation in the Joint Declaration, and by making important inroads into the abductions issue. 
However, since 2004 Japan has appeared largely unable to exploit these opportunities for enhanced engagement with North Korea. Japan has had greater opportunities to engage North Korea with the loosening of international pressures following the Bush's administration's determination of its need for a diplomatic resolution to the nuclear crisis and the initiation of the SPT in Beijing since August 2003. Japan's freedom of action internationally has been further enhanced with South Korea's determination to push ahead with its own engagement of the North. Moreover, even as the Bush administration has begun since late 2005 and the stagnation of the SPT process to enhance its pressure on North Korea through the tightening of financial sanctions, it has still searched for means to engage the North diplomatically and to restart the SPT, thus looking to achieve a balance of containment and engagement.

Nonetheless, the domestic political pressures on the Japanese government to shift its own policy towards containment have markedly grown since late 2004, with Japan's consideration of a range of sanctions, illustrated in the table below. In March 2006, the LDP further ramped up the pressure by submitting a bill that would force the government to impose sanctions if North Korea failed to make progress on resolving the abductions issue. ${ }^{14}$ The sanctions proposed are the most extensive, and potentially deep-biting of any of the three phases of Japan-North Korea relations. Moreover, Japan's move towards these sanctions has been largely unilateral, and often in contravention of US requests to refrain. The evidence then is of a shift in this third phase towards containment in Japan, even if at increasing loggerheads to international pressures. 
Table: Japan's economic sanctions on North Korea as of 2005

\begin{tabular}{|c|c|c|c|c|c|}
\hline & Specific measures & Background, significance and objective & Legal basis & $\begin{array}{l}\text { Procedures } \\
\text { for } \\
\text { enactment }\end{array}$ & State of progress \\
\hline \multirow[t]{5}{*}{$\begin{array}{l}\text { Direct } \\
\text { economic } \\
\text { sanctions }\end{array}$} & $\begin{array}{l}\text { Tightening of procedures for the } \\
\text { reporting of remittances }\end{array}$ & \multirow[t]{4}{*}{$\begin{array}{l}\text {-enables Japan to impose sanctions unilaterally, } \\
\text { whereas it previously required cooperation of UN or } \\
\text { one or more states }\end{array}$} & \multirow[t]{4}{*}{$\begin{array}{l}\text { Foreign Exchange } \\
\text { and Foreign Trade } \\
\text { Law (FEFTL) }\end{array}$} & $\begin{array}{l}\text { Ministry of } \\
\text { Finance } \\
\text { ordinance }\end{array}$ & \multirow[t]{4}{*}{ Revised 9 February 2004} \\
\hline & Stoppage of remittances & & & \multirow{4}{*}{$\begin{array}{l}\text { Cabinet } \\
\text { decision, } \\
\text { followed by } \\
\text { National } \\
\text { Diet } \\
\text { approval }\end{array}$} & \\
\hline & $\begin{array}{l}\text { Prohibition of import of specific } \\
\text { items }\end{array}$ & & & & \\
\hline & $\begin{array}{l}\text { Total cessation of trade with } \\
\text { North Korea }\end{array}$ & & & & \\
\hline & $\begin{array}{l}\text { Prohibition on entry into } \\
\text { Japanese ports of North Korean } \\
\text { shipping }\end{array}$ & $\begin{array}{l}\text {-includes all North Korean shipping, but chief target } \\
\text { is Manyongbong-92 passenger ship that serves as } \\
\text { main transport link for physical carrying of } \\
\text { remittances via Niigata }\end{array}$ & $\begin{array}{l}\text { Law to Prevent } \\
\text { Designated Ships } \\
\text { From Visiting } \\
\text { Japanese Ports }\end{array}$ & & Enacted 14 June 2004 \\
\hline \multirow{5}{*}{$\begin{array}{l}\text { Measures } \\
\text { equivalent } \\
\text { to } \\
\text { economic } \\
\text { sanctions, } \\
\text { or 'virtual' } \\
\text { sanctions }\end{array}$} & $\begin{array}{l}\text { Stoppage of food aid to North } \\
\text { Korea }\end{array}$ & & \multicolumn{2}{|c|}{ None required } & Imposed December 2004 \\
\hline & $\begin{array}{l}\text { Consistent labelling of asari } \\
\text { (short-neck clams) as products } \\
\text { of North Korean origin }\end{array}$ & $\begin{array}{l}\text {-asari constitute } 22 \% \text { of Japanese imports from } \\
\text { North Korea } \\
\text {-enables Japanese consumers to voluntarily boycott } \\
\text { North Korean products }\end{array}$ & $\begin{array}{l}\text { Japan Agricultural } \\
\text { Standards (JAS) Law }\end{array}$ & $\begin{array}{l}\text { Ministry of } \\
\text { Agriculture, } \\
\text { Forestry and } \\
\text { Fisheries } \\
\text { regulation }\end{array}$ & Enacted June 2004 \\
\hline & $\begin{array}{l}\text { Obligatory insurance for North } \\
\text { Korean ships over } 100 \text { tons in } \\
\text { displacement }\end{array}$ & $\begin{array}{l}\text {-only } 2.8 \% \text { of North Korean ships have the necessary } \\
\text { insurance } \\
-¥ 100 \text { million premium thought prohibitive for the } \\
\text { North }\end{array}$ & $\begin{array}{l}\text { Law on Liability for } \\
\text { Oil Pollution Damage }\end{array}$ & & Revised 1 March 2005 \\
\hline & $\begin{array}{l}\text { Support for North Korean } \\
\text { asylum seekers }\end{array}$ & $\begin{array}{l}\text {-instructs central and local government to provide } \\
\text { asylum seekers with passage to third countries and } \\
\text { long term residence in Japan } \\
\text {-encourages political defections and the } \\
\text { destabilisation of North Korean regime }\end{array}$ & $\begin{array}{l}\text { Bill for law for relief } \\
\text { of human rights } \\
\text { infringements } \\
\text { relating to North } \\
\text { Korea }\end{array}$ & & $\begin{array}{l}\text { Submitted for deliberation to } \\
\text { the National Diet February } \\
\text { 2005; resubmitted February } \\
2006\end{array}$ \\
\hline & $\begin{array}{l}\text { Tightening of supervision of } \\
\text { Chōsensōren-affilitated credit } \\
\text { unions, or Chōgin }\end{array}$ & $\begin{array}{l}\text { - Chōgin collapsed in 1990s suspected as the result of } \\
\text { illegal channelling of funds to North Korea } \\
\text {-Japanese politicians in } 2003 \text { attempted to obstruct } \\
\text { use of } ¥ 1.4 \text { trillion of public bail-out funds } \\
\text { - government has provided funds, but on condition } \\
\text { of appointment of Japanese nationals as Chögin } \\
\text { presidents }\end{array}$ & $\begin{array}{l}\text { Cooperative } \\
\text { Associations Services } \\
\text { Law }\end{array}$ & $\begin{array}{l}\text { Financial } \\
\text { Services } \\
\text { Authority } \\
\text { regulation }\end{array}$ & \\
\hline
\end{tabular}




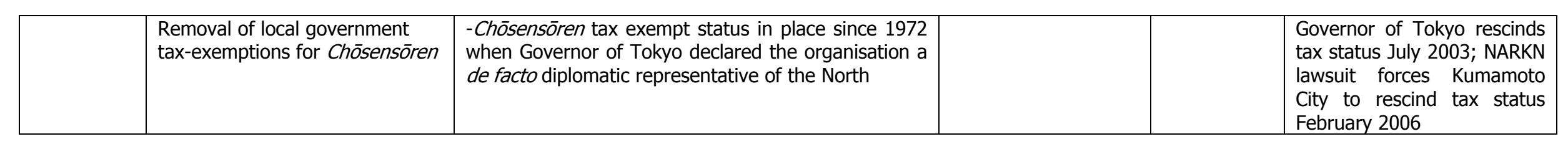




\section{Japan's sanctions policy and domestic coalitions}

In the decade since the first North Korean nuclear crisis, the underlying trend in Japan's North Korea policy has been a strengthening shift from a position of default engagement to one of default containment, as witnessed in its consideration of unilateral sanctions. Japan's government has been increasingly pushed towards a position of containment, which it is difficult to back out of, or for pressure from the international system to overcome. Domestic political conditions have not just been an important and constant variable in shaping Japan's policy shift over the last decade, but are now also challenging international factors in setting the overall orientation of policy. In turn, this focus on the increasingly vital role of domestic politics vis-à-vis the international system reinforces the argument at the outset of this article that it is only possible to explain Japan's move towards sanctions and its overall North Korea policy by examining the nature of coalitions within its domestic political economy.

\section{MOFA}

The starting point for this examination is MOFA, charged as it is with the central role in devising and implementing Japan's North Korea policy through balancing domestic political pressures and the international systemic pressures of managing relations with the US, South Korea and other regional powers. MOFA has persisted in seeking engagement towards North Korea since the 1990s, recognising the potential benefits for Japanese and regional security, and wishing to obviate a conflict with the North.

However, MOFA's ability to pursue a consistent policy of engagement has been hampered by the activities of Japanese politicians engaged in 'individual' (kojin gaikō) and 'dual diplomacy' (nijū gaikō), as in the case of Kanemaru in 1990. MOFA 
has gradually clawed back control of the negotiating agenda by patiently building up its own direct links with the North Korean elites, and thereby making redundant the negotiating 'pipes', or links, that the politicians have maintained with North Korea. Tanaka Hitoshi as Director General of the Asian and Oceanian Affairs Bureau (AOAB) from September 2001 until December 2002, and then later as the Deputy Minister for Foreign Affairs until July 2005, was particularly instrumental in boosting the role of MOFA in controlling the negotiating agenda with North Korea by enlisting the support of the Prime Minister's Office, or Kantei, and Koizumi himself, in conducting secret diplomacy with the North leading up to the 2002 summit.

However, MOFA's ability and inclination to engage North Korea since the late 1990s has subsequently been hampered by the ministry's domestic political weaknesses. MOFA's policy-making influence has been debilitated by its engulfment in financial scandals since 2001; the damaging appointment of Tanaka Makiko from April 2001 to January 2002 that left the ministry adrift from political influence; and the resultant loss of senior personnel. ${ }^{15}$ In turn, MOFA officials involved with North Korea diplomacy_including Makita Kunihiko, the former Director General of the AOAB from 1998 until September 2001, and Tanaka Hitoshi-have been the subject of acerbic media and political attacks.

Added to this climate of personal professional and physical risk, MOFA has been hindered by its internal divisions. Tanaka's conduct of 'secret diplomacy' (himitsu gaikō) with North Korea in the run-up to the 2002 summit, with limited consultation with the other MOFA bureaus, drew considerable internal criticism from the North American Affairs Bureau (NAAB), fearful of the impact on ties with the US. 
Moreover, since the slowing of the momentum for improvements in Japan-North Korea ties after the initial successes of the 2002 summit, the internal balance of influence within the ministry has increasingly shifted towards personnel in favour of containment. Takeuchi Yukio, the Vice-Minister for Foreign Affairs and Japan's top diplomat from February 2002 until December 2005, although experienced in North Korea affairs since his spell as Deputy Director of AOAB at the time of the 1995 Watanabe mission, was aligned more closely with NAAB and a known opponent of Tanaka's style of diplomacy. ${ }^{16}$ Tanaka was largely protected in his position by his close ties to Koizumi. However, Koizumi's relatively declining interest in North Korea affairs after the 2004 summit and preoccupation with domestic reforms removed Tanaka's influence, and he accepted early retirement in 2005. Meanwhile, Takeuchi himself has been replaced by Yachi Shōtarō, known to be close to both Koizumi and former Deputy Chief Cabinet Secretary Abe Shintarō, and generally hard-line on engagement and sanctions towards North Korea. ${ }^{17}$ In addition to these bureaucratic personnel changes, political changes in leadership have compounded MOFA's negative stance towards engagement: Machimura Nobutaka, the Foreign Minister from November 2004 to October 2005 freely indicated that the imposition of sanctions was one means to pressure the North over the abductions issue; and his successor Asō Tarō is a known hard-liner on North Korea. ${ }^{18}$

\section{Prime Minister's Office}

The Prime Minister's and the Kantei's increasingly important role in proactive Japanese diplomacy has been noted in response to the 'war on terror' in Afghanistan and Iraq since 11 September 2001, but the core executive's role has been equally crucial in coordinating North Korea policy. ${ }^{19}$ Koizumi essentially ran much of Japan's 
North Korean diplomacy from the Kantei and bypassed normal MOFA channels in the run-up to the 2002 and 2004 summits, entrusting the preparations to Tanaka Hitoshi and Fukuda Yasuo, the then Chief Cabinet Secretary. ${ }^{20}$ From late 2004, Koizumi has relied less on Tanaka Hitoshi, and more on his old LDP political ally, Yamasaki Taku, acting in a special advisory role until his re-election to the Diet in April 2005.

Koizumi's willingness to risk his political credibility on North Korea, and his ability to force through policy by relying on a small group of advisors, has been crucial not only for the breakthroughs made on the abductions issue in 2002 and 2004, but also for restraining anti-North Korean domestic political pressure thereafter. Koizumi appears to have often removed from influence those officials who might wish to take a hard-line stance: engineering, for instance, the resignation in September 2004 of Nakayama Kyōko, a former Cabinet liaison officer between the government and abductee relatives, who had publicly criticised Yamasaki's and LDP member Hirasawa Katsuei's secret meeting with North Korean officials in April 2004. ${ }^{21}$ Koizumi has also frequently attempted to restrain domestic pressure for the sanctions option. For instance, in the Diet in March 2004, Koizumi referred to sanctions as a 'glittering sword' that once unsheathed may prove double-edged in effectiveness, because it may indicate the seriousness of Japan's intent to North Korea, but also set Japan on a path to using this tool and conflict with the North. ${ }^{22}$

Koizumi's capability to restrain anti-North Korea domestic pressures, however, is doubtful over the longer term. Koizumi is genuinely convinced of the benefits for Japanese and regional security in seeking to engage North Korea, but has also found 
significant, if declining, domestic political utility in his summit diplomacy in the North. Opinion polls taken immediately after Koizumi's visit to the North in 2002 demonstrated an eighty one per cent approval for his diplomatic actions, with a boost in support for the Cabinet from fifty one to sixty one per cent; and then Koizumi's second visit in 2004 received a seventy per cent approval rating, but with no significant boost for the Cabinet's approval rate. ${ }^{23}$ An Asahi Shimbum opinion poll in December 2004 also demonstrated that sixty three per cent of respondents were in favour of sanctions. ${ }^{24}$

Hence, even though Koizumi has shown signs of returning to the North Korea normalisation issue at the end of his period of office - knowing that it will be his final opportunity to establish a historic foreign policy legacy - the diminishing domestic returns of North Korea diplomacy, has meant that he has devoted less consistent policy attention and political energy on active engagement. It appears that Koizumi has been increasingly content to allow Abe Shinzō, as the newly appointed Chief Cabinet Secretary in October 2005, to use the Prime Minister's Office as a powerbase to pursue the abductions issue. Koizumi has continued to restrain Abe from initiating any definite move to sanctions, but has nevertheless allowed him to pursue a topdown style of decision-making that has frequently sidelined MOFA's negotiating channels and intimated Japan's willingness to use sanctions as a means to force a resolution to the abductions issue. ${ }^{25}$

$L D P$

The LDP as the governing party, singly or in coalition from 1955 to 2005, and with the exception of August 1993 to June 1994, has played a crucial role in the history of 
Japan-North Korea relations through the individual diplomacy of key party leaders and through domestic political support for government-level negotiations. Of all the Japanese domestic actors, however, the LDP has exhibited the most radical turnaround in its position on North Korea-moving from a position of default engagement for nearly the entire post-war period to one of default containment from the late 1990s onwards - with a profound impact on the overall make-up of domestic coalitions predisposed towards the containment of the North.

From the early to the late 1990s, a number of key LDP politicians demonstrated interest in the normalisation of ties with the North in order to clear up the legacy of colonialism and contribute to regional stability, but also for domestic political gain. Kanemaru's visit to North Korea in 1990 may have been motivated in large part by potential financial gains for his Takeshita Noboru faction. Kanemaru is rumoured to have received money directly from the Chōsensōren, the umbrella organisation of the North Korean community in Japan, and associated businesses such as the pachinko industry; from the North Korean government (notoriously including gold ingots found in his secretary's safe during the Sagawa Kyūbin investigations of 1993); and from the construction industry eager to gain access to cheap supplies of salt-free alluvial building gravels (jari) in the North, a resource for high-quality concrete largely exhausted in Japan. Most crucially, Kanemaru's willingness to promise compensation to the North in the Three-Party Declaration may have been explained by his ambition to secure these as a source of factional funds. For if Japan were to provide up to US\$10 billion in the form of ODA and 'economic cooperation', then the Takeshita faction as the initiator of these funds could have expected a 'kickback' of at least one per cent, or $¥ 50$ billion, from North Korea and Japanese companies awarded aid 
contracts, and that would have allowed it to prolong its domination of Japanese politics. ${ }^{26}$ Indeed, it is clear that the Takeshita faction and its predecessor Tanaka Kakuei faction had long eyed North Korea ties as their factional property and the last great untapped source of political funds. Prime Minister Tanaka was the first Japanese premier to attempt to improve ties with North Korea in the period of détente in the mid-1970s; the original Dietmen's League for the Promotion of Japan-North Korea Friendship (Nicchō Yūkō Sokushin Giin Renmei, or Nicchō Giren) was founded in 1971 by Kuno Chūji, a Tanaka faction member; and it was Prime Minister Takeshita who first opened the way for Kanemaru's mission with an apology in the Diet in March 1989 to North Korea for wartime damage.

The LDP's other factions and 'policy tribes' (zoku) have at various times shown an interest in North Korea. House of Representatives and Watanabe Michio faction members Tani Yōichi and Nakayama Masaaki were consistent proponents of improved ties with the North. Nakayama, for instance, serving from 1997 as Chairman of the Nicchō Giren. Watanabe himself led the LDP-SDPJ-Sakigake mission to North Korea in 1995; and the then number two in the faction, Yamasaki Taku, has been involved in individual diplomacy with the North since the mid-1990s. Katō Kōichi as Chairman of the LDP's Policy Affairs Research Council (PARC), number two in the Miyazawa Kiichi faction, and a close political associate of Yamasaki in the mid-1990s, also became intimately connected with North Korea in this period. Katō persuaded Watanabe to visit North Korea and then negotiated the direct provision of rice aid to the North in 1995. The motivations for the interest of the Watanabe faction members and Katō are various. Tani and Nakayama represented Kansai region constituencies with a high proportion of North Korea residents, and, 
although they have undoubtedly been motivated by the desire to address the colonial legacy and assist the humanitarian cause in the North with rice aid, the suspicion is that they may also have received money from groups associated with the Chōsensōren. Tani, Watanabe and Katō were also noted members of the agricultural tribe (nōrin zoku) in this period, and the suspicion is that their desire to provide rice aid was a measure designed to clear government stockpiles and thereby force up demand and the price of domestic rice for their supporters in the agricultural community. ${ }^{27}$ Indeed, the LDP's nōrin zoku at other instances have shown an interest in engaging North Korea only when there is an opportunity for the dumping of rice stocks through the provision of food aid—Japan's decision in 2000 to provide rice aid was critically backed by the zoku in PARC's Foreign Affairs Division. ${ }^{28}$

Nevertheless, despite the interest displayed by other LDP groups, North Korea diplomacy up until the late 1990s remained very much the province of the TanakaTakeshita faction lineage. The Hashimoto Ryūtarō and Obuchi Keizō factions as the successor factions moved to reassert control over the issue in the mid-1990s, seemingly fearful that the likes of Kato might attempt to utilise diplomacy with the North not only to strengthen support amongst the agricultural zoku, but also to gain control of the ODA resources, and use normalisation as a springboard to move the Miyazawa faction into a dominant position in domestic politics. The HashimotoObuchi faction ensured that it retained its grip on North Korea policy through Katō's effective exclusion from power during the Hashimoto administration; through Obuchi's appointment as Foreign Minister in September 1997 and his initial early enthusiasm for normalisation; and through the ability of Nonaka Hiromu, a key faction member and later Chief Cabinet Secretary with very close ties to the North 
Korean community in Japan and the North's regime, to engineer the Mori mission to the North in November 1997 and the December 1999 Murayama mission.

Hence, although competing amongst themselves for influence and control of the issue, the LDP's factions throughout the 1990s envisaged considerable domestic political incentives in working to engage North Korea. These incentives were sufficiently strong to carry forward the LDP's default engagement position even in the wake of the 'Taepdong-shock'. However, a concatenation of other factors, including the Taepdong incident and the growing revelations relating to the abductions, meant that in the late 1990s the LDP began to its shift towards default containment.

The LDP's shift has in part been initiated by personnel changes. The pro-North Korea lobby in the LDP has been blunted by the deaths of Watanabe, Kanemaru, and Obuchi in 1995, 1996 and 2000 respectively, the neutralisation of Katō's influence, the retirement of Nonaka from national politics in 2003, and the resignation of Fukuda from the post of Chief Cabinet Secretary in 2004. Just as importantly, though, it is clear that many of these LDP figures had already become disenchanted with North Korean affairs or lost influence due to the rising political risks of association with the North. Kanemaru received severe intra-party and media criticism due to his concessions during the 1990 mission and rumours of his receipt of money from the North, thereby contributing to his eventual political downfall in the Sagawa Kyūbin scandal. Similarly, Katō was vilified by sections of the media for his individual diplomacy in 1995; and Nonaka heavily criticised for his support for engagement even in the face of mounting evidence over the abductions. LDP figures have also faced physical threats similar to those of MOFA officials. 
In addition, LDP politicians see not only rising political and physical risks in engaging North Korea, but also declining opportunities for compensatory financial gains. The Chōsensōren's financial difficulties since the early 1990s have gradually reduced its ability to funnel money to politicians, and any flows from the North are under severe public scrutiny. Koizumi's accession to the premiership and subsequent personal intervention in North Korea diplomacy has largely removed this issue from the purview of the LDP factions. Moreover, Koizumi's systematic destruction of the Hashimoto faction as an internal opposition force has removed it as the one major grouping capable of generating momentum for engagement from within the governing party.

By contrast, the incentives for LDP members to switch to support for containment have grown since the late-1990s. The LDP old-guard have been replaced by younger politicians, less dependent on factional financial support and with no links to the Chōsensōren, but more conscious of national security issues, and often from constituencies of the abductee families and prepared to campaign on this specific vote-winning issue. Most notable amongst this new breed of 'neo-conservative' LDP politicians is Abe Shinzō, the former Chairman of the LDP Countermeasures Headquarters for the North Korea Abduction Issue (Kitachōsen ni Yoru Rachi Mondai Taisaku Honbu) and the former Chairman of the Cabinet Abduction Issue Task Force (Rachi Mondai Tokumei Chìmu), and current Chief Cabinet Secretary, who in his bid to succeed Koizumi as prime minister has made significant political play out of his support for the families of the abductees. ${ }^{29}$ For instance, Abe in April 2006 used his position as Chief Cabinet Secretary to push for the conduct of DNA tests that established that husband of Yokota Megumi was also a probable South Korea 
abductee. Abe then timed the public release of this evidence to coincide with unofficial SPT talks in Japan so as to generate maximum embarrassment for the North Korean representative visiting Tokyo. ${ }^{30}$ Abe was further responsible for initiating the meeting between President W. Bush and Yokota's family in Washington D.C. in the same month in attempt to raise public consciousness of the abductions issue in the US but especially Japan. ${ }^{31}$

Abe has been joined in his efforts to press the abduction issue by Hirasawa Katsuei, serving as Chairman of the Parliamentarian League for the Early Repatriation of Japanese Citizens Kidnapped by North Korea (Kitachōsen Rachi Sareta Nihonjin o Sōki ni Kyūshutsu Suru Tame ni Kōdō Suru Giin Renmei, or Rachi Giren)—a crossparty group formed in October 2002 as a breakaway from the Niccho Giren in opposition to Nakayama's soft-line on the North, and also working closely with the Association of Families of Victims Kidnapped by North Korea (AFVKN) (Kitachōsen ni Yoru Rachi Higaisha Kazoku Renrakukai, or Kazokukai). The Rachi Giren subsequently passed a resolution that Japan should not normalise relations with North Korea until after a resolution of the abductions issue. ${ }^{32}$ Hirasawa, despite his antiNorth Korea credentials received harsh media criticism for his and Yamasaki's secret diplomacy with the North in April 2004, forcing him to resign from the organisation. Hirasawa was then succeeded as chairman of the Rachi Giren by Nakagawa Shōichi and then Hiranuma Takeo, both former Ministers of Trade Economy and Industry (METI) and noted right-wingers (although Hiranuma eventually left the LDP in October 2005 in protest at Koizumi's postal reforms). Other LDP figures highly critical of North Korea and that have offered public support for sanctions include former Foreign Minister Kōmura Masahiko; the current Environment Minister Koike 
Yuriko; and the former Director General of the Japan Defence Agency Ishiba Shigeru, and younger politicians critical of the North include Aisawa Ichirō the current Chairman of the LDP Countermeasures Headquarters for the North Korea Abduction Issue, Yamamoto Ichita, the current head of the LDP's sanctions simulation team, and Kōno Tarō. ${ }^{33}$ Koike and Yamamoto have particularly fought against the allocation of funds to the Chogin.

The LDP's near complete shift to default containment is demonstrated by Abe's free talk of the need to precipitate 'regime change' in North Korea, and his LDP countermeasures group laying out on 9 December 2004 a specific five-step timetable for sanctions on the North. ${ }^{34}$ The shift in the party is also hinted at by opinion polls of Diet members and candidates taken by the National Association for the Rescue of Japanese Kidnapped by North Korea (NARKN) (Kitachōsen ni Rachi Sareta Nihonjin o Kyūshutsu Tame no Zenkoku Kyōgikai, or Sukūkai) taken in December 2004 and prior to the House of Representatives election of September 2005. Although figures produced by an organisation pressing for sanctions need to be handled with care, they do offer some reflection on the mood of the party, with both polls indicating respectively that eighty five and seventy two per cent of respondents were in favour of the early imposition of sanctions. ${ }^{35}$

\section{Coalition and Opposition Parties}

The LDP's New Kōmeitō coalition partner since 1998 has generally maintained a pronormalisation stance, but it too has shifted towards talk of containment and pressing the North on the abductions issue, thus jointly submitting the March 2006 LDP bill obliging the government to impose sanctions if no progress is made on the abductions 
issue. ${ }^{36}$ The SDPJ prior to and since Kanemaru's visit has maintained close relations with the North. The SDPJ's former Secretary General, Tanabe Makoto, was a signatory to the Three Party Declaration in 1990, and the SDPJ was part of the Watanabe and Mori missions in 1995 and 1997; former SDPJ Prime Minister Murayama led a mission in December 1999; and other SDPJ figures with close ties to the North have included the former SDPJ President Doi Takako, former SDPJ Secretary General Itō Shigeru, former House of Representatives member Funada Hajime, and the House of Councillors member Den Hideo. The SDPJ proved extremely influential in determining North Korea policy at the time of the first nuclear crisis, firmly resisting as a member of the coalition government in early 1994 any move to accede to US pressure for the imposition of sanctions. ${ }^{37}$

Nevertheless, the SDPJ's ability to influence domestic politics in favour of engagement with North Korea is now spent. The LDP since Kanemaru's visit has succeeded in establishing its own links with the North's regime, thereby rendering the role of the SDPJ largely redundant. In addition, the SDPJ's influence has been eroded by its own internal splits and decline in electoral fortunes, leaving it with only eleven seats in the Diet. The SDPJ's older generation of pro-North Korean Diet members has faded away, with the loss of Tanabe, Itō, Funada, and most recently in the September 2005 election Doi, leaving only the eighty-two year old Den active in politics. In fact, Doi's North Korean connections had already contributed to her electoral difficulties, with her defeat in the November 2003 election in a single member constituency by Ōmae Shigeo, an LDP newcomer, campaigning strongly on the abductions issue; although Doi was eventually returned under proportional representation. Meanwhile, 
the new SDPJ membership has displayed less sympathy with North Korea, voting in favour of the revised FEFTL in $2004 .^{38}$

The Democratic Party of Japan (DPJ) since its formation in 1998 has displaced the SDPJ as the main opposition party, but it too has offered little support for engagement of the North. The DPJ as an initial amalgam of other political parties has exhibited a variety of positions on North Korea. Former DPJ leaders, Kan Naoto and Hatoyama Yukio as members of the Sakigake participated in the Watanabe mission of 1995; the DPJ has contained former LDP members such as Ishii Hajime, who as a member of the Tanaka faction accompanied the Kanemaru mission in 1990; and former SDPJ members such as Kubo Wataru with close links to the North. However, the younger generation of DPJ leaders and members has shifted the party more towards containment and sanctions. Okada Katsuya, DPJ President until September 2005, pressed for North Korea's full cooperation in the abductions issue; and Hatoyama, now signalling his turnaround in position by becoming head of the DPJ's own countermeasures team on the abductions, called in November 2004 for the investigation of sanctions in response to the Yokota case. ${ }^{39}$ Ozawa Ichirō, the new leader of the DPJ since April 2006, has had dealings with North Korea in the past from his time as a member of the Takeshita faction, and following on from the Kanemaru mission visited the North in October 1990 to bring home the crew of the Fujisanmaru 18. However, since his departure from the LDP in 1993, Ozawa has shown little interest in engagement with North Korea.

The DPJ has also attempted to rival the LDP by stating a desire in its November 2003 and September 2005 election manifestos to resolve the abductions issue through the 
potential use of sanctions; the DPJ cooperated with the LDP on the Law to Prevent Designated Ships From Visiting Japanese Ports in June 2004; and in February 2005 the DPJ submitted a bill similar to that of the LDP to assist North Korean defectors. ${ }^{40}$ The DPJ also formerly contained the right-wing figure of Nishimura Shingō, known for his vehemently anti-North Korean stance; although he has been expelled from the party since November 2006 due to unconnected corruption charges. Meanwhile, the NARKN surveys of 2004 and 2005 showed over sixty per cent of DPJ respondents in favour of sanctions. ${ }^{41}$

\section{Local Government}

Japan's local government authorities have further shifted the balance of domestic coalitions towards containment. Ishihara Shintarō has utilised his position as Tokyo Governor to berate the Japanese government for its soft stance on North Korea's security provocations and the abductions, and pursued the Chōsensōren by leading the campaign to remove its tax-exempt status. The NARKN has also pushed hard on this issue, winning a court decision in February 2006 forcing Kumamoto City to rescind the tax status of local Chōsensōren facilities. Local authorities have pressured against engagement in a number of other ways. The prefectural assemblies of Fukuoka, Kumamoto and Kanagawa submitted letters to Koizumi in 2002 urging the government to be 'firm' in negotiations with the North on the abductions and normalisation; the Mayor of Niigata petitioned the government in June 2003 to halt the port calls of the Mangyongbong-92; and the Niigata prefectural assembly the following month provided the governor with the right to refuse entry to poorly equipped ships. Niigata Prefecture's action again represents a turnaround in attitude, 
with many of the prefectures along the Sea of Japan coast having been keen in the early 1990 s to improve political and economic ties with the North.

\section{Chōsensōren}

The role of the Chōsensōren and the North Korean community in Japan in encouraging other domestic actors to engage the North has waned significantly since the mid-1990s. The Chōsensōren has been increasingly bypassed as a channel for bilateral ties since the establishment of the LDP's and Japanese government's own direct links with the North since the early 1990s. Added to this, the Chōsensōren's ability to provide financial incentives has declined. The post-bubble recession hit the receipts of the pachinko industry, produced the collapse and increased regulation of the Chogin, and the decline in remittances to the North. For instance, Japan's Ministry of Finance estimated that the total flow of remittances through official channels, already in decline since the 1990 s, had fallen to $¥ 4$ billion in 2002 ( $¥ 400$ million in bank transfers; $¥ 3.6$ billion in cash delivered by visitors to North Korea), and then further fell to $¥ 2.7$ billion in 2003 ( $¥ 101$ million bank transfers, and $¥ 2.57$ billion in cash deliveries). ${ }^{42}$

\section{Business interests}

Japanese business interests, and especially large corporations, have long occupied a potentially key role in creating momentum for engagement with North Korea, as in the case of the role of private business sector actors in pushing for normalisation with China in the 1970s. However, in practice large businesses have tended to abdicate their policy role in dealing with North Korea since the early 1990s. 
Japanese businesses have certainly had a major interest in North Korea from the 1970s onwards. During the period of détente, a number of large Japanese companies looked to set up operations in the North in order to export its mineral resources, leading to a major expansion of bilateral trade. But Japan-North Korea economic ties subsequently deteriorated due to North Korea's inability to repay up to US\$900 million in accumulated debts to Japanese companies; an issue that remains largely unresolved to this day. Japanese construction companies again showed an interest in North Korea at the time of the Kanemaru mission, as explained above, and some interest in the North's Rajin-Sonbong Free Economy and Trade Zone initiated in 1991. Japanese large businesses have remained interested in the North's resources, and a group of ten construction companies planned to send a mission to the North in October 2004 to investigate possible ODA construction projects that might be realised after normalisation. ${ }^{43}$ However, Japanese large businesses are yet to act on these plans due to the continuing debt issue, the lack of central government support through providing export credits, and the political uncertainties of doing business with the North - the group of construction companies eventually shelving their trip to North Korea for fear of a public backlash in the wake of the Yokota case. ${ }^{44}$

Instead, Japan-North economic ties have been left principally to small business activities. Chōsensōren-affilitated companies and Japanese medium and small enterprises companies have done vigorous trade in cheap business suits, textiles, and in matsutake and marine products. These business interests offer some resistance to sanctions, expressing concerns that measures to complicate trade with the North such as boycotting asari will affect their business, and also that the revised insurance laws on shipping will have a knock-on impact on trade with Russian shipping. ${ }^{45}$ But the 
small-scale nature of these businesses, and lack of allies amongst larger scale corporations, means that they have little practical influence over the growing disposition of domestic coalitions towards containment. In the meantime, Japan-North Korea trade continues to contract overall, falling to a twenty-eight year low in 2005 of US\$190 million (compared to around 500 million dollars for most of the 1980s and 1990s), and accounted for Japanese consumers' boycotts of North Korea goods and the enhanced regulations on North Korean exports and shipping. ${ }^{46}$

\section{Conclusion: Japanese Domestic Politics as a Driver of North Korea Policy}

The detailed examination above of Japanese sanctions policy demonstrates that, if the attitudes of key and pluralistic domestic policymakers are aggregated, it is possible to discern a number of important trends in Japan's overall approach towards North Korea. Firstly, domestic policymakers have come to form a series of cross-cutting coalitions that have shifted Japanese attitudes from a position of default engagement to one of increasingly default containment. Japan's domestic policymakers, although generally in favour of engagement of the North at the time of the first North Korean nuclear crisis, began to shift towards containment after the mid-1990s and in the aftermath of the 'Taepdong-shock'. This shift has intensified following, and in many ways in spite of, Koizumi's diplomacy with the North from 2001-2006. In addition, although Japanese domestic political actors have at times pursued this trend in fitful bursts and even reversed their position, the overall trend has been towards hardening on engagement, with progressively fewer signs of a willingness to backslide on sanctions. Hence, MOFA's engagers have been marginalised by those taking a hardline on the North; the Kantei has played a decisive but often only sporadic role in engagement, and is increasingly being used to forge policies of containment under 
Abe's influence; the LDP has shifted from being a party of engagement to one of containment; the SDPJ has evaporated as a force for engagement and been replaced by the DPJ increasingly seeking to rival the LDP on its hard-line stance; local government has reinforced the containment trend; the North Korean community in Japan has declining resources to generate support for engagement; and the business community is currently disinterested in engagement.

Secondly, Japan's domestic policy-actors in pursuing these coalition-forming trends have generally been consistent in acting against or with disregard for international pressures. At the time of the first North Korean nuclear crisis, Japan's policymakers, by holding out for limited engagement, came close to setting themselves at opposition to international systemic pressures. Following the first nuclear crisis to the period of Koizumi's diplomacy, Japan's domestic coalitions have reversed their position and set themselves more towards containment, even as the international system, with fluctuations, has increasingly looked towards creating opportunities for engagement.

Thirdly, and most crucially, it must be observed that the move of Japanese domestic coalitions towards containment, whilst kicking against the trends in international systemic pressures, has not just coincided with, but clearly triggered actual policy changes within Japan with regard to containment. These are such that Japan, more than at any other time in the previous decade, now actively possesses the capability and the policy will to impose sanctions on the North. The conclusion is that Japan's domestic political coalitions are affecting and driving real policy change towards containment, and that it is progressively challenging, if not beginning to override international pressures in determining the overall policy orientation. 
Japan's policy behaviour on shifts towards containment and sanctions, therefore, affirms the theory of domestic sanctions put forward in this article. Japan's domestic policymakers are on the brink of forming a 'threshold coalition' that is generating increasing pressure to tip government policy towards the imposition of sanctions. In many cases, Japan's domestic policymakers have been motivated to pursue both instrumental sanctions that are aimed at undermining the North Korean regime, and 'expressive' sanctions that despite talk of 'regime change' may not inflict critical damage on the North but do demonstrate general abhorrence towards the regime over the abductions and other security issues. The case study presented above also conforms with theory by demonstrating that crucial factors in the formation of the domestic coalition have been not only the growing disinclination of large policy actors to engage North Korea, but also the ability of smaller actors, such as the NARKN and AFVKN, to manipulate the pressure of public opinion in order to solidify the coalition. ${ }^{47}$ Domestic sanctions theory is further affirmed by the fact that big business interests, as a possible source of momentum for turning back to engagement, have largely abdicated their role in the policy process, thereby opening up space for usually less influential actors to shape the containment agenda. Finally, domestic sanctions theory is reinforced because the nature of Japanese domestic coalitions indicates that they are now increasingly capable of capturing the initiative in pushing government policy towards containment, even to the point of contravening international pressures.

In terms of overall conclusions, this article argues that Japanese policy behaviour over the past decade can only be adequately explained by a focus on its domestic 
determinants, and, concomitantly, that international pressures are both insufficient and declining in their explanatory quality. This study of Japan's North Korea policy, viewed as increasingly driven by domestic politics, thus complements other studies that have looked to domestic sources to explain Japanese foreign and security policy behaviour. However, it also makes a further contribution to this body of literature by indicating theoretically and empirically the particular dynamic process and conditions, in the shape of the formation of 'threshold' coalitions, by which domestic politics becomes increasingly decisive in shaping policy outcomes.

In turn, the focus on domestic policy actors as key in determining Japan's North Korea policy offers important conclusions about the level of Japan's cooperation in dealing with the current nuclear crisis and its significance in Korean Peninsula security affairs. Japanese domestic coalitions' increasing disposition towards the containment of the North means that Japan is not likely to bend easily, or at all, to conform to US and South Korean efforts to engage the North, even if the SPT and other attempts to resolve the nuclear crisis progress. Japan's government, restrained by domestic political pressures, may prove obdurate in providing crucial financial resources to support US-led attempts to persuade the North to dismantle its nuclear programme. Japan's non-cooperation may thus serve to magnify its importance in Korean Peninsula affairs, even if this is ascribed to Japan's undermining international efforts to deal with the North.

Japan's government might yet break out of the restraints of domestic political pressures. Although Koizumi's summitry heightened the importance of the abductions issue in Japan, it also succeeded in making important headway in a resolution to the 
issue and in establishing an agreed negotiating agenda for normalisation. Furthermore, the full weight of international pressures has not yet been brought to bear on Japanthe US possibly pushing Japan much harder to conform with engagement policy if it sees Japan as an obstacle to an imminent resolution to the nuclear issue. Japan might also yet be spared a clash with its ally, if the US itself, increasingly frustrated at the lack of progress in the SPT shifts decisively towards containment and sanctions; although the US's basic policy remains one of seeking a negotiated resolution through balanced policies of engagement and pressure. Nevertheless, the fundamental lesson from the last decade of Japan-North Korea relations will still remain: Japan's domestic political pressures have set much of the pace for government policy, and, without any significant weakening of domestic coalitions pushing for containment, then these domestic pressures are likely to continue to trip up, or even fully block, international efforts for engagement.

\section{Postscript}

At the time of the final preparation of this article in August 2006, Japan has imposed new sanctions on North Korea in response to its missile tests the preceding July. Japan's government on 5 July immediately implemented unilateral sanctions to ban the entry into Japan of the Manyongbong-92, of North Korean charter flights, and North Korean officials. Japan has further investigated the implementation of the full range of sanctions outlined in the Table in this article, and later in the month tightened restrictions on trade in possible components for the North's missile programmes.

Japan's measures have further served to confirm the arguments of this article. Firstly, the North's missile tests have brought the pro-sanctions threshold coalition fully to the 
surface. Koizumi has played some role in restraining the adoption of the full panoply of sanctions, but he has ceded leadership on the North Korean issue to his presumptive successor Abe, with a resultant hardening of domestic pressures to contain the North. Secondly, Japan's sanctions have been imposed often in opposition to prevailing international pressures. Japan has worked with the US to construct UN resolution 1659, condemning North Korea's tests and requiring member states to prevent the transfer to the North of missile technology and components. Nevertheless, despite US-Japan cooperation at the UN level, the Bush administration overall has been averse to stronger sanctions on the North. The US remains wary of provoking Chinese opposition and jeopardising any prospects for the restart of the SPT in order to address its main priority of resolving the nuclear issue. Japan's focus on the missile issue and its drive for sanctions, largely inspired by domestic pressures and largely out of kilter with Chinese, Russian, South Korean and even US strategic priorities, thus threatens to render it further isolated and obstructive in Korean Peninsula security affairs.

\footnotetext{
${ }^{1}$ For elaboration of this point, see Hagström in this special issue.

2 “Don’t Sanction Pyongyang Yet: US,” Japan Times Online. 15 December 2004 [Online cited 17 August 2005]. Available from $\quad<$ http://www.japantimes.co.jp/cgibin/getarticle.pl5?nn20041215a3.htm>.

${ }^{3}$ For realist perspectives applied to Japan, see Kenneth A. Waltz, "The Emerging Structure of International Politics," International Security, vol. 18, no. 2 (1993), pp. 44-79; Christopher Twomey, “Japan, a Circumscribed Balancer,” Security Studies, vol. 9, no. 4 (2000), pp. 167-205; Jennifer Lind, "Pacifism or Passing the Buck? Testing Theories of Japanese Security Policy," International Security, vol. 29, no. 1 (2004), pp. 92-121.

${ }^{4}$ For an overview of recent discussions of international systemic versus domestic political explanations of Japan's foreign policy, see Robert Pekkanen and Ellis S. Krauss, “Japan's 'Coalition of the Willing' on Security Policies," Orbis: A Journal of World Affairs, vol. 49, no. 3 (2005), pp. 429-444; and Glenn
} 
D. Hook, Julie Gilson, Christopher W. Hughes and Hugo Dobson, Japan's International Relations: Politics, Economics and Security, Second Edition (London: Routledge, 2005), pp. 44-77.

${ }^{5}$ For an examination of the impact of sanctions, see Kimberley Ann Elliot, The Role of Economic Leverage in Negotiations with North Korea, DPRK Briefing Book, The Nautilus Institute. [Online, $\begin{array}{lllll}\text { citied } & 27 & \text { September } & \text { 2005]. } & \text { Available }\end{array}$ $<$ http://www.nautilus.org/DPRKBriefingBook/sanctions/Elliott.html >.

${ }^{6}$ Lisa L. Martin, Coercive Cooperation: Explaining Multilateral Sanctions (Princeton: Princeton University Press, 1992), pp. 9, 241-247.

${ }^{7}$ Gary Clyde Hufbauer and Barbara Oegg, "Beyond the Nation State: Privatisation of Economic Sanctions," Middle East Policy, vol. 10, no. 2 (2003), pp. 126-134.

${ }^{8}$ William H. Kaempfer and Anton D. Lowenberg, "Using Threshold Models to Explain International Relations,"Public Choice, vol. 73, no. 4 (1992), p. 420.

${ }^{9}$ Johan Galtung, "On the Effects of International Economic Sanctions: With Examples from the Case of Rhodesia," World Politics, vol. 19, no. 3, (1967), pp. 378-416; William H. Kaempfer and Anton D. Lowenberg, "Sanctioning South Africa: The Politics Behind the Policies," Cato Journal, vol. 8. no. 3 (1989), pp. 714-715; and James M. Lindsay, "Trade Sanctions As Policy Instruments: A Reexamination," International Studies Quarterly, vol. 30, no. 2 (1986), p. 156.

${ }^{10}$ Richard Farmer, "Costs of Economic Sanctions to the Sender," The World Economy, vol. 23, no. 1 (2000), p. 94.

${ }^{11}$ Christopher W. Hughes, Japan's Economic Power and Security: Japan and North Korea (London, Routledge, 1999), p. 111.

${ }^{12}$ Izumi Hajime, Yun Duk-Min, Tanaka Hitoshi, "Chōsen Hantō no Heiwa to Antei wa Nihon ni Totte no Shikatsu Mondai da," Gaikō Fōramu, no. 173 (2002), p. 18.

${ }^{13}$ Tanaka Hitoshi and Tahara Sōichirō, Kokka to Gaikō (Tokyo: Kōdansha, 2005), pp. 27-29.

${ }^{14}$ Nihon Kokkai Shūgiin, "Racchi Mondai Sonota Kitachōsen Tōkyoku ni Yoru Jinkengai Mondai e no Taisho Hi Hansuru Hōritsuan.” $\quad$ Available from http://www.shugiin.go.jp/index.nsf/html/index_gian.htm>.

${ }^{15}$ Shinoda Tomohito, Kantei Gaikō (Tokyo: Asahi Shimbunsha, 2004), pp. 51-126.

${ }^{16}$ Yakushiji Katsuyuki, Gaimushō: Gaikōryoku Kyōka e no Michi (Tokyo: Iwanami Shinsho, 2003), pp. $45-48$. 
17 “Gaimujikan Kyōkoha ni,” Yomiuri Shimbun, 14 January 2005, p. 4.

${ }^{18}$ Personal interview with senior official, North East Asia Division, AOAB, MOFA, Tokyo, 2 September 2005.

${ }^{19}$ Christopher W. Hughes, Japan's Re-emergence as a 'Normal' Military Power, Adelphi Paper 368-9 (Oxford: Oxford University Press/IISS, 2004), pp. 62-64.

${ }^{20}$ Yakushiji, Gaimushō, p. 16.

21 “Key Advisor on North Korea Calls It Quits,” Japan Times Online. 30 September 2004 [Online cited, 19 September 2005]. Available from <http://www.japantimes.co.jp/cgibin/getarticle.pl5?nn20040930a2.htm>.

${ }^{22}$ Kokkai Shūgiin Kaigiroku Yosaniinkai (National Diet House of Representatives, Budget Committee Minutes) 18gō, 16 March 2003, p. 17.

${ }^{23}$ Shinoda, Kantei Gaikō, p. 71-72; “70\% Positive on Koizumi Trip: Poll,” Japan Times Online. 25 May 2004 [Online cited, 19 September 2005]. <Available from http://www.japantimes.co.jp/cgibin/getarticle.p15?nn20040525a2.htm>.

24 “Kitachōsen Seisai Sansei 63\%," Asahi Shimbun, 21 December 2004, p. 1.

25 “Kantei Shudō Taiwa e Atsuryoku,” Asahi Shimbun, 12 April 2004, p. 1.

${ }^{26}$ Tamura Tatsuo, "Sengo Hoshō Riken '500okuen'," in Nomura Hataru (ed.) Kitachōsen Riken no Shinsō, (Tokyo: Takarajimasha, 2004), pp. 161-162.

${ }^{27}$ Ingocuhi Takashi and Iwai Tomoaki, Zoku Giin no Kenkyū (Tokyo: Nihon Keizai Shimbunsha, 1987), p. 296; Aoki Eichi, "Miira Tori ga Miira ni Natta: Rekidai 'Haji Shirazu' Hōchōdan Gyōjōroku,” in Nomura (ed.) Kitachōsen Riken no Shinsō, pp. 75-76.

${ }^{28}$ Yakushiji, Gaimushō, pp. 167-168.

${ }^{29}$ Yamaguchi Jirō, Sengo Seiji no Hōkai (Tokyo: Iwanami Shinsho, 2004), pp. 49-54.

30 “Rokusha Rainichi ni Pitari," Asahi Shimbun, 12 April 2006, p. 2.

31 “Kita e Atsuryoku Nichibei ga Kōo,” Asahi Shimbun, 29 April 2006, p. 1.

${ }^{32}$ Yakushiji, Gaimushō, pp. 33-34.

33 “Takamaru Keizai Seisairon,” Asahi Shimbun, 17 December 2004, p. 4.

34 “Datsuhokusha, Nihon Ukeire Mo," Asahi Shimbun, 4 February 2005, p. 3; "Yurugu Taiwa Rōsen," Asahi Shimbun, 17 December 2004, p. 4. 
35 “Kitachōsen e no Keizai Seisai ni Kansuru Kokkai Giin Ankēto Kekka,” Sukū Kai Zenkoku Kyōgikai [Online, cited 8 January 2004]. Available from http://www.sukuuka.jp; "Rachi Higaisha Kyūshutsu no Tame no Sōki Seisai Hatsudō ni Kansuru Zentōsensha Ankēto Kekka,” Sukū Kai Zenkoku Kyōgikai [Online, cited 15 September 2005]. Available from <http://www.sukuuka.jp/H17enquete_result/>.

36 “Yoyatō, Seron Mikiwame e," Asahi Shimbun, 16 November 2004, p. 4

${ }^{37}$ Christopher W. Hughes, “The North Korean Nuclear Crisis and Japanese Security,” Survival, vol. 38, no. 2 (1996), p. 92.

38 “SDP to Vote for Pyongyang Sanctions Bill," Japan Times Online, 29 January 2004 [Online, cited 19 September 2005]. Available from <http://www.japantimes.co.jp/cgibin/getarticle.p15?nn20040129a2.htm>.

39 “Yoyatō, Seron Mikiwame e,” Asahi Shimbun, 16 November 2004, p. 4.

40 “Minshutō Kyōsai Hōan Teishutsu”, Asahi Shimbun, 25 February 2005, p. 2.

41 “Kitachōsen e no Keizai Seisai”, Sukū Kai Zenkoku Kyōgikai [Online, cited 8 January 2004]. Available from http:/www.sukuuka.jp; "Rachi Higaisha Kyūshutsu”, Sukū Kai Zenkoku Kyōgikai [Online, cited 15 September 2005]. Available from <http://www.sukuuka.jp/H17enquete_result/>.

42 “Remittances to North Korea Way Down,” Japan Times Online. 13 February 2005 [Online, cited 21 September 2005]. Available from $\quad<$ http://www.japantimes.co.jp/cgibin/getarticle.p15?nn20050213a7.htm>.

${ }^{43}$ For rumours of Japanese interest in the North's mineral resources, see Harada Takeo, Kitachōsen Gaikō no Shinjitsu (Tokyo: Chikuma Shobō, 2005), pp. 68-79.

44 “North Korea boycott see some impact," Japan Times Online. 12 January 2005 [Online cited, 22 September 2005]. Available from $\quad<$ http://www.japantimes.co.jp/cgibin/getarticle.pl5?nn20050112f1.htm>; Hughes, Japan's Economic Power and Security, pp. 131-144.

45 “Kitachōsensan Kani Mokuteki ni,” Asahi Shimbun, 1 February 2005, p. 2.

46 “Trade with Pyongyang at lowest since 1977 at mere \$190 million,” Japan Times Online. 14 February 2006 [Online cited, 24 May 2006]. Available from http://search.japantimes.co.jp/cgibin/nb20060214a6.html.

${ }^{47}$ For elaboration of the role of the NARKN and AFVKN, see Lynn in this special issue. 